\title{
Inflammation, Metalloproteinases, Chronic Venous Disease and Sulodexide
}

\author{
Alberto C. Frati Munari ${ }^{1 *}$ and Luis Fernando Flota Cervera ${ }^{2}$ \\ ${ }^{1}$ Department of Internal Medicine, Médica Sur Hospital, Puente de Piedra 150-1-929, Toriello Guerra, Tlalpan, México D.F. 14050, México \\ ${ }^{2}$ Director CEDIME Instituto Vascular, Calle 33 - 138, Mérida Yuc. 97129, México
}

\begin{abstract}
Inflammation and extracellular Matrix Metallo Proteinases (MMPs) have been recently considered as an important step in the pathogenesis of Chronic Venous Disease (CVD). To understand how inflammation and MMP may affect venous tissue, a review on these items and on the pathogenesis of CVD was performed. Prolonged or repeated venous hypertension due to well-known predisposing factors causes abnormal shear stress leading to shredding of endothelial glycocalyx and activation of endothelial cells. The latter expose adhesion molecules and release pro-inflammatory cytokines. Diapedesis follows, leading to leukocytes infiltration of Extra Cellular Matrix $(E C M)$ in the sub endothelial space of vein walls and valves. Activated leukocytes, mainly monocytes-macrophages, release chemotactic cytokines that amplify the inflammatory response, they also produce Nitric Oxide molecules (NO) and proteases, including MMPs. High concentration of MMPs, especially MMP-9, is found in venous wall with CVD and in venous ulcers. The role of MMP-9 in CVD is also supported by experimental data. MMP-9 can degrade components of ECM as collagen, elastin, fibronectin and laminin. MMP-9 and other proteolytic enzymes may disrupt ECM structure, damaging and debilitating venous wall that lead to varicose veins and venous ulcers.
\end{abstract}

Sulodexide, a glycosaminoglycan, counteracts several of these inflammatory changes. In subjects with CVD administration of sulodexide improves venous hemodynamic changes and CVD symptoms and accelerates venous leg ulcers healing.

Keywords: Varicose veins; Inflammation; Metalloproteinases; MMP; Venous leg ulcers; Sulodexide; Chronic venous disease; Venous insufficiency.

\begin{abstract}
Abbreviations: CGRP: Calcitonin Gene Related Product; COX: Cyclooxygenase; CVD: Chronic Venous Disease; C2,C3,C4: Clinical stages 2, 3 and 4 of CEAP Classification for CVD; ECM: Extra Cellular Matrix; EGF: Epidermal Growth Factor; FGF: Fibroblast Growth Factor; G-CSF: Granulocyte Colony Stimulating Factor; GM-CSF: Granulocyte-Monocyte Stimulating Factor; HSP: Heat Shock Protein; ICAM: Inter Cellular Adhesion Molecule; IL: Inter Leukin; LDL: Low Density Lipoprotein; LPS: Lipo Poly Saccharide; MCP-1: Monocyte Chemotactic Protein-1; MIP-1 $\beta$ : Macrophage Inflammatory Protein-1 beta; NFkB: Nuclear Factor kappa B; NO: Nitric Oxide; PDGF: Platelet Derived Growth Factor; $\mathrm{PGE}_{2}$ : Prosta Glandin $\mathrm{E}_{2}$; ROS: Reactive Oxygen Species; SEM- Scanning Electron Microscopy TGF $\beta$ : Transforming Growth Factor beta; TIMP: Tissue Inhibitor of Metallo Proteinase; TNFa, TNF $\beta$ : Tumor Necrosis Factor alfa, beta; VCAM: Vascular Cell Adhesion Molecule; VEGF: Vascular Endothelial Growth Factor
\end{abstract}

\section{Introduction}

In recent years, multiple evidences have emerged that strongly support the involvement of inflammation and extracellular Matrix Metallo Proteinases (MMP) production as a fundamental step in the pathophysiology of Chronic Venous Disease (CVD), in both its appearance and its progression to the most advanced stages, i.e., venous leg ulcers. However, the inflammatory process, from its origin to the production of MMP and the consequent deterioration of venous walls and their valves which leads to CVD, may be complicated and it frequently requires an integral explanation. The purpose of this review is to organize these concepts and facilitate the knowledge on the participation of the inflammatory process in the pathophysiology of CVD.

\section{Inflammation General Concepts}

Inflammation is a physiological response of the body to aggression.
It can be caused by biological agents (e.g., an infection), chemical agents (e.g., oxidative substances such as oxygen reactive species), physical agents (e.g., heat) or mechanical agents (e.g., trauma or vessel shear stress). The inflammatory phenomenon is essential for survival, since it tends to protect the organ and repair the damage, ultimately its objective is the return to normal conditions. Aggression can be of exogenous or endogenous origin. Sometimes, the inflammatory response may cause damage to tissues and organs, as occurs in autoimmune diseases.

The main signs of inflammation were desribed by Celsus (Aulus Cornelius Celsus; ca. 25 b. C. - 50 a. C.): heat, redness, tumor (volume increase) and pain; 200 years later, Galen of Pergamon added function loss or alteration (functiolaesa), which was confirmed by Virchow. The common substrate of inflammation is the leukocytic infiltrate which is nearly always preceded by vasodilation with an increase in vascular permeability that causes fluid exudation (edema).

Inflammation is a complex defense mechanism in which leukocytes migrate from inside the vessels towards the damaged tissue to destroy the agent causing tissue damage. Acute inflammation is a limited beneficial response, particularly during an infection, while chronic inflammation is a persistent phenomenon that may lead to tissue damage. One characteristic of acute inflammation is that initially, the leukocyte infiltrate consists of neutrophils, but after 24 to 48 hours monocytes predominate. In contrast, chronic inflammation is

*Corresponding author: Alberto C. Frati Munari, Department of Internal Medicine Médica Sur Hospital, Puente de Piedra 150-1-929, Toriello Guerra, Tlalpan, México D.F. 14050, México, Tel: (52)5556665847; E-mail: AFrati@alfawassermann.com

Received April 30, 2015; Accepted May 29, 2015; Published June 01, 2015

Citation: Munari ACF, Cervera LFF (2015) Inflammation, Metalloproteinases, Chronic Venous Disease and Sulodexide. J Cardiovasc Dis Diagn 3: 203. doi:10.4172/2329-9517.1000203

Copyright: @ 2015 Munari ACF, et al. This is an open-access article distributed under the terms of the Creative Commons Attribution License, which permits unrestricted use, distribution, and reproduction in any medium, provided the original author and source are credited. 
associated with mononuclear cell infiltrate: monocytes-macrophages and lymphocytes. The leukocyte infiltrate is the main characteristic that allows the pathologist to recognize the presence of inflammation under the microscope $[1,2]$.

\section{How is vasodilation produced?}

A noxious agent stimulates certain cells: mast cells, endothelial cells and macrophages, as well as free nervous endings that release different chemical mediators, which dilate the arterioles and venules and increase fluid and protein leakage. Mast cells thus activated produce histamine, eicosanoids (thromboxanes, prostaglandins, leukotrienes), tryptases and CGRP (Calcitonin Gene Related Product), which cause arteriolar dilation. Endothelial cells produce Nitric Oxide (NO), $\mathrm{PGI}_{2}$ and convert kallikrein into bradykinin, which are substances that also cause arteriole dilation. Activated macrophages cause arteriolar vasodilation and increased vascular permeability by the action of Cyclooxygenase (COX), which converts arachidonic acid into $\mathrm{PGE}_{2}$, they also produce NO. Free nervous endings release $P$ substance and neurokinins, which stimulate mast cells and cause venular vasodilation and permeability increase. The greater vascular permeability enables the presence of a water and protein exudate and facilitates the leukocytic infiltrate [3].

\section{How is the leukocytic infiltrate produced?}

The noxious agent that prompts any cell alteration causes damaged cells of any kind to release heat shock proteins or HSP that act on tissue macrophages, smooth muscle cells and endothelial cells. Thus activated endothelial cells express adhesion molecules on their surface: ICAM - Inter Cellular Adhesion Molecule, VCAM - Vascular Cell Adhesion Molecule, E and P selectins. The three types of cells produce cytokines, especially Interleukins (IL) which regulate and amplify inflammation [3].

Cytokines are soluble proteins released by some cells and they act as a chemical messenger between the cells involved in immunity and inflammation, IL among them, produced mainly by different types of leukocytes, tumoral necrosis factor, interferons and various growth factors [4]. Endothelial cells and smooth muscle cells produce IL-6, macrophages produce IL-1, IL-6, IL-12 and IL-15 which modulate inflammation and the immune response, macrophages also produce TNF- $\alpha$ (Tumor Necrosis Factor $\alpha$ ) and nitric oxide which is a vasodilator. IL-1 $\alpha$ and TNF- $\alpha$ contribute to the expression of adhesion molecules in endothelial cells. IL-6 is pleiotropic, it has various proinflammatory actions, among which change from a neutrophil infiltrate to a monocyte-macrophage infiltrate in the extracellular matrix stands out, it participates in the regulation of the immune response and in the production of acute phase reactants [5,6]. The exposure of adhesion molecules on the surface of endothelial cells and also on leukocyte's surface (L-selectin, integrins) causes these to circulate more slowly and finally adhere to endothelial cells, to later penetrate into the intercellular spaces until reaching the extracellular matrix (diapedesis).

The participation of the endothelial glycocalyx in inflammation is essential. An intact glycocalix rejects leukocytes and prevents these from approaching adhesion molecules. Mechanical tensile, frictional or shear stresses on vascular walls, as well as hyperglycemia, oxidized LDL, some enzymes and tumor necrosis factor TNF- $\alpha$ may cause sufficient glycocalyx thinning for small adhesion molecules to become exposed to leukocytes, thus, these may adhere and migrate towards the ECM beyond the endothelium $[7,8]$. Activated leukocytes produce IL and chemokines, which attract more leukocytes and increase the inflammatory infiltrate in the extracellular matrix. Chemokines are small molecules $(8-12 \mathrm{kD})$, there are around 50 , they induce chemotaxis and they recruit leukocytes; at some point they also recruit fibroblasts that initiate lesion healing or tissue remodeling [4].

\section{Inflammation as a cause of extracellular matrix damage}

Besides production of different cytokines, both endothelial cells and activated leukocytes produce Reactive Oxygen Species (ROS) that may oxidize different exogenous substances (for example, phagocytized bacteria) but also components of the body itself. Leukocytes also produce different enzymes that break protein peptide bonds (proteinases), such as elastase, cathepsin G, proteases and extracellular matrix metalloproteinases. Elastase hydrolyzes elastin and fibronectin, it also detaches a leukocyte coating, thus exposing integrins, facilitating their adhesion and transmigration towards the ECM, which induces the production of ROS and more proteinases. Cathepsin $\mathrm{G}$ is produced by neutrophils and it is important for the digestion of phagocytized material. Proteases digest proteins and peptides of different kinds. MMPs are worthy of being considered separately. Proteinases and ROS may damage the extracellular matrix structure. Extracellular proteolysis appears to be a prerequisite for normal wound and injured tissue healing, but excessive or uncontrolled tissue destruction may be a pathogenic factor leading to tissue damage and remodeling [3]. The main aspects of inflammation development are summarized in (Figure $1)$.

\section{Extracellular Matrix Metalloproteinases (MMPs)}

Metalloproteinases are produced by several cells, especially leukocytes. Their physiological function is in the turnover, regulation and composition of the extracellular matrix components, therefore, they are present in all tissues. They are designated as metalloproteinases due to the presence of zinc at the active site.

There are more than $20 \mathrm{MMP}$, but they can be divided into 5 groups according to their structure and specificity [9]

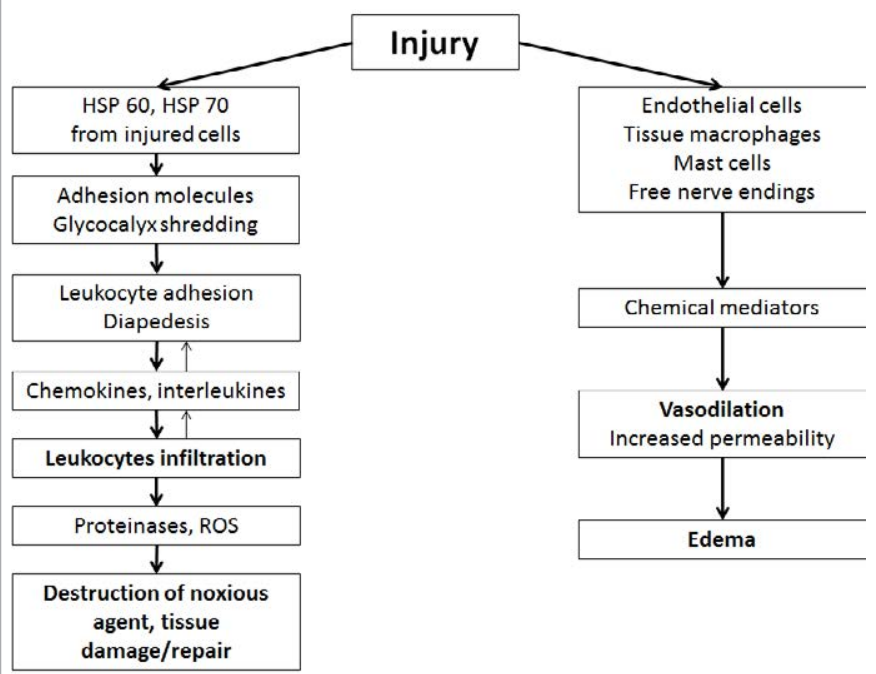

Figure 1: General diagram of inflammation. The two main histologic features are leukocyte infiltration and vasodilation. The first initiate with heat shock proteins inducing leukocyte adhesion and diapedesis. Leukocyte infiltration is enhanced by chemokines produced mainly by macrophages, leukocytes release MMPs and other proteinases, as well as reactive oxygen species, leading to the destruction of noxious agent. Vasodilation is produced through several chemical mediators such as histamine, eicosanoids, bradykinin, $\mathrm{PGE}_{2}$, nitric oxide released by endothelial cells, mast cells, macrophages and nerve endings. Vasodilation and increased vascular permeability causes edema. 
- Collagenases, which degrade type I, II, III and X fibrillar collagen (MMP-1, 8 and 13).

- Gelatinases, which degrade denatured collagen, laminin, fibronectin, elastin and basement membrane type IV collagen (MMP 2 and 9).

- Stromelysins, which degrade proteoglycans, laminins, fibronectin and some types of collagen (MMP-3,10,11 and 12).

- Matrylisin, which degrade type IV collagen and proteoglycans (MMP-7)

- Membrane metalloproteinases, which degrade several components of ECM (MMP-14 to 17).

They are secreted as zymogens and must be activated (by plasmin, ROS and other enzymes) to exert their proteolytic action. They are inhibited by TIMP (Tissue Inhibitors of Metallo Proteinase). MMP production is kept in balance with its tissue inhibitors, but the balance is broken in the presence of inflammation (and of additional activated monocytes-macrophages). Pro-inflammatory cytokines: IL-1, IL-6, TGF- $\beta$ (transforming growth factor $\beta$ ), TNF- $\alpha$, EGF (epidermal growth factor), PDGF (platelet-derived growth factor) increase their synthesis, while corticosteroids, heparin and IL-4 slow down their synthesis [10].

MMPs have been considered important in vascular diseases for the following reasons:

a) A marked increase in MMP-9 plasma concentration was found in blood drawn from varicose veins after 30 minutes of stasis (in orthostatic posture) [11].

b) Greater amounts of different MMP with variations in distribution have been observed in varicose vein walls, compared to normal veins. MMP-9 has been found at higher concentrations in the middle layer of varicose veins $[12,13]$.

c) In rat vena cava rings subjected to tension, it was demonstrated, by means of immune-histochemical staining, that the rise of tension markedly increases the presence of MMP-2 and MMP-9 in the middle layer. MMP-2 and MMP-9 concentration was higher with greater tensile strength. The greater the tensile strength $(2 \mathrm{~g}$ vs. $0.5 \mathrm{~g})$ and its duration (24 hours vs. 1 hour), the higher the MMP-2 and MMP-9 concentration $(\mathrm{p}<0.01)$. Moreover, MMPs increase coincides with a reduction in the contraction strength of the venous wall induced by phenylephrine, angiotensin II and potassium chloride, an effect prevented with TIMP, thus demonstrating that contractility reduction is totally or partially due to MMP increase. The direct effect of MMP2 and MMP-9 on venous contraction capacity was proved by the incubation of vena cava segments with these MMPs, contractility is lower as incubation time elapses, this effect is also counteracted with TIMP [14].

d) The importance of MMPs in venous ulcers is supported by various studies that demonstrate the increase of MMP in the ulcerated tissue, mainly in chronic ulcers or ulcers of torpid evolution. MMPs concentration is higher in chronic ulcers than in acute ulcers $[15,16]$.

e) Specifically, MMP-9 is found at higher concentrations in fluid from chronic ulcers than in fluid from acute ulcers. The high concentration of MMP-9 in ulcers is associated to an unfavorable evolution and it is reduced in ulcers during compressive treatment or in ulcers that are in healing process [17-20].

f) In diabetic foot ulcers, the initial MMP-9 concentration is also associated with the outcome: those with low MMP-9 concentrations heal rapidly, while those with high concentrations have a more chronic evolution [21].

g) Administration of MMP-9 to experimental skin ulcers in mice delays healing [22].

\section{Pathophysiology of Chronic Venous Disease}

There are two main groups of causative or predisposing factors in the appearance of CVD: genetic and environmental factors. Besides some genetic syndromes accompanied by venous disorders, which are sometimes very marked, the influence of inheritance is certain in "common" CVD cases and it has been demonstrated in multiple observations. If both parents have varices, the risk of developing CVD is very high (90\%), while if one parent is affected the risk is $25 \%$ for men and $62 \%$ for women [23]. Maternal influence is greater than paternal influence, with the former involving a risk of around $50 \%$ and the latter a $25 \%$ risk [24]. In Mexico, it was observed that more than $60 \%$ of 1,013 patients with CVD had history of maternal varicose veins [25]. The mechanism of genetic predisposition is not clear enough, but it is likely to be related to venous wall or valve weakness, or both. Other predisposing factors, such as obesity, multiparity, prolonged standing, previous venous thrombosis, etc. [24-26] have a clear haemodynamical influence, since they delay blood flow return and they chronically elevate hydrostatic venous pressure in a repeated and prolonged way.

Venous hypertension increases mechanical tensile, frictional or shear stresses which act on the endothelial glycocalyx and endothelial cells. Glycocalyx becomes thinner and endothelial cells are activated [27]. It has been demonstrated that the increase in venous pressure causes an increase of endothelial adhesion molecules [28]. A recent review of the influence of blood flow alterations and shear stress on the endothelium reveals that these induce the expression of pro-oxidant, pro-inflammatory, pro-coagulant and pro-apoptotic genes in endothelial cells, as well as the expression of adhesion molecules, leukocyte adhesion and diapedesis and the increase of metalloproteinases and ROS [29].

Examination of the endothelial surface of surgical samples of saphenous veins with CVD by SEM (scanning electron microscopy), compared with control saphenous veins without venous disease show an irregular orientation, discontinued areas of the endothelium, plates and erythrocytes adhered to the surface and the presence of "microvilli" on endothelial cell surface. The abnormalities were of greater severity in more severe degrees $(\mathrm{C} 4>\mathrm{C} 3>\mathrm{C} 2)$. In the same study, endothelial cells from veins (saphenous veins and tertiary branches R3) from healthy controls and patients with CVD show clear differences between the groups: the expression of surface molecules, adhesion molecules (ICAM-1), the proliferation, transcriptional activity (NFkB), proinflammatory cytokine release and VEGF capacity are greater in CVD grade $\mathrm{C} 3$ than in grade $\mathrm{C} 2$, and are greater in these than in control individuals. In short, during CVD, endothelial cells show a proinflammatory phenotype whose intensity depends on the degree of CVD [30].

The degradation of the glycocalyx and the inflammatory activation of the endothelium enable diapedesis and leukocyte infiltration of the vein walls. In this respect, more than 15 years ago, with the use of monoclonal antibodies, Ono et al. identified the presence of monocyte/ macrophage infiltrate in the venous walls and valves in all the ten saphenous veins of patients with venous disease and in no saphenous vein of four individuals without venous disease [31]. 
The inflammatory infiltrate originates the release of proteinases (mainly MMP) and other enzymes that degrade the ECM. Moreover, a pro-oxidative state has been demonstrated in CVD, since an increase of oxidative substances and a reduction in antioxidants has been found in plasma from patients with CVD compared to healthy volunteers [32]. The role of oxidative stress in venous wall damage is not clear, but it is probably a contributing factor.

The degradation of the extracellular matrix weakens the venous wall and allows vein dilation and valve impairment, which in turn increases reflux and worsens venous hypertension. An imbalance of the protein content of ECM of varicose vein walls has been proven, which appears even before the presence of valves insufficiency Although inflammation also occurs in venous valves, deforming them or even damaging them until disappearance, some evidences suggest that venous dilation appears first, followed by valves incompetence [33,34]. Valves dysfunction worsens venous hypertension, and the pathophysiological circle increases.

The same changes that affect glycocalyx and endothelial cells occur in venules and capillaries, which explains edema, skin disturbances and venous ulcers. The increase of water permeability causes edema, whose consistency increases due to the passage of proteins, erythrocyte filtration causes ochre dermatitis, diapedesis towards the skin and the subcutaneous tissue favors inflammation which, together with local ischemia due to alterations of capillary flow, leads to the emergence of skin ulcers [27]. The involvement of inflammation in venous disease and microcirculation in the pathophysiology of lipodermatosclerosis and skin ulceration has been recognized since many years ago and it has recently been reviewed incorporating the current concepts $[35,36]$.

In venous ulcers, a high concentration of multiple proinflammatory cytokines, such as various interleukins, granulocyte and granulocyte-monocyte colony stimulating factors, monocyte chemotactic protein-1, interferons $\gamma$ and $\alpha$ and other has been demonstrated; many of these decrease after 4 weeks of treatment. High concentrations of anti-inflammatory cytokines are also found in ulcers that later heal faster [37]. This inflammatory activity is consistent with high MMP-9 concentrations, especially in ulcers with unfavorable evolution and its reduction with treatment and healing, as previously mentioned. In keeping with the foregoing, the proteomic analysis of exudate collected from rapidly healing ulcers shows proteins that take part in tissue formation, while that of non-rapidly healing ulcers rather show inflammatory and tissue destruction proteins, such as MMP-9, elastase and proteinase 3 [20].

Involvement of inflammation in the pathophysiology of chronic venous disease, including skin disturbances, is summarized in (Figures 2 and 3 ).

\section{Pleiotropic anti-Inflammatory Therapeutics in CVD}

Although there are many anti-inflammatory drugs, most of them are cyclooxygenase inhibitors and they have not been shown to have favorable actions in CVD. In contrast, the glycosaminoglycan sulodexide has shown utility in CVD, since it has different actions in the pathophysiology of CVD [38-40] as follows:

- It restores impaired glycocalyx volume. For example: the glycocalyx dimension observed in the sublingual vessels of individuals with type 2 diabetes mellitus is lower than in healthy controls. After two months of treatment with sulodexide administered by oral route, the dimensions of the glycocalyx increased reaching normal values [41].

- It suppresses the inflammatory-type response of endothelial cells.
Cultured endothelial cells subjected to high glucose concentrations or to ageing changes release free radicals (reactive oxygen species), monocyte chemotactic protein-1 and interleukin 6 and reduce their multiplication rate, measured as the time of recovery from a wound. These alterations are prevented when sulodexide is added to the culture medium $[42,43]$.

- It reduces the release of interleukins, chemokines, and colonystimulating factors by macrophages. In an in vitro experiment in cell culture, lipopolysaccharide (LPS)-stimulated macrophages significantly increase the production of cytokines, chemokines and colony-stimulating factors, when sulodexide is added at two different

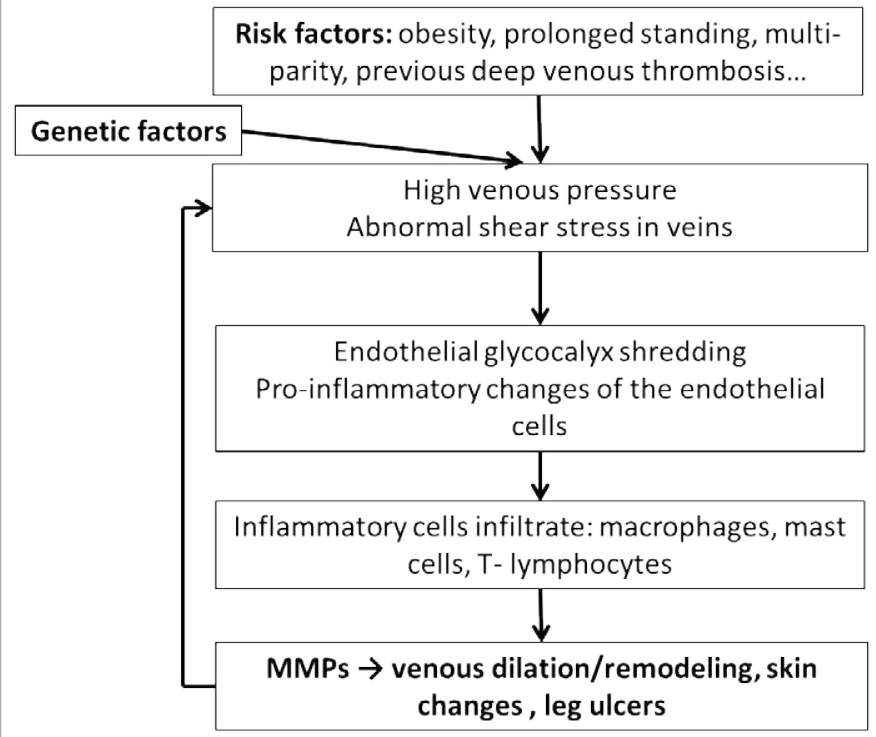

Figure 2: Simplified diagram of pathophysiology of chronic venous disease. The initial step seems to be chronic or repeated high venous pressure, inflammation causes permanent damage of the vein walls and valves leading to venous insufficiency and higher venous pressure in a vicious cycle. Modified from Raffetto and Mannello [38]

Consequences of glycocalyx and endothelium changes in venules and capillaries

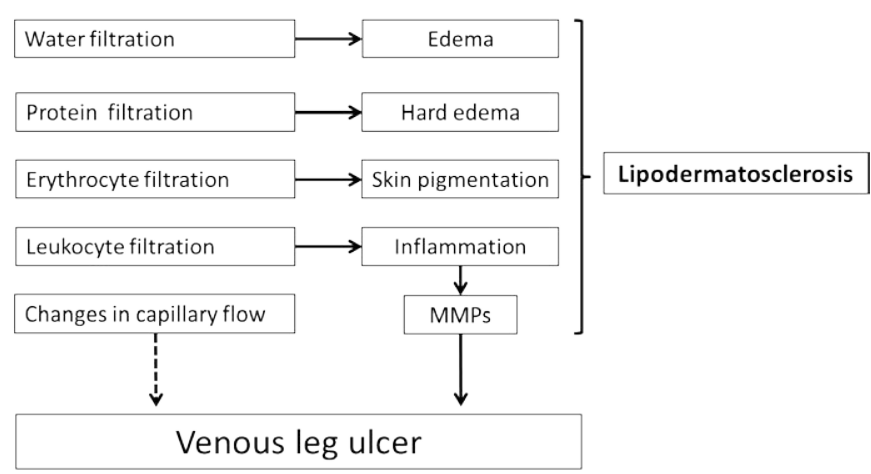

Figure 3: The inflammatory endothelial and glycocalyx changes in the presence of venous hypertension, enable skin inflammation, including local production of proteolytic enzymes (mainly MMP) that eventually lead to the destruction of skin areas with ulcer formation. Capillary blood flow is regulated by endothelium including glycocalyx, changes in blood flow, may be an important contributing factor in the pathophysiology of leg ulcers. 
Citation: Munari ACF, Cervera LFF (2015) Inflammation, Metalloproteinases, Chronic Venous Disease and Sulodexide. J Cardiovasc Dis Diagn 3: 203. doi:10.4172/2329-9517.1000203

concentrations to previously stimulated macrophages a dose-dependent inhibition of the release of various interleukins is observed: IL-1B, IL12 and TNF-alpha, which are proinflammatory, IL-7 and IL-17, which are immune-modulatory, several cytokines with chemotactic activity, such as interleukin 8 , monocyte chemotactic protein-1 (MCP-1) and macrophage inflammatory protein $\beta$ or MIP $1 \beta$, as well as granulocyte colony-stimulating factor (G-CSF) and granulocyte-monocyte colony-stimulating factor (GM-CSF). In the same experiment, a doseindependent inhibition of other interleukins was observed: IL-2, IL-6, IL-10, IL-13 and interferon $\beta$ [44].

- It reduces MMP-9 secretion by macrophages. The incubation of blood from healthy volunteers with increasing sulodexide

\begin{tabular}{|c|c|c|}
\hline \multicolumn{3}{|c|}{ Anti-inflammatory actions of sulodexide } \\
\hline Action & $\begin{array}{l}\text { Experimental } \\
\text { system }\end{array}$ & Probable implication \\
\hline \multicolumn{3}{|c|}{ On the regulation of inflammatory response } \\
\hline $\begin{array}{l}\text { Reduction of monocyte } \\
\text { chemoattractant protein-1 } \\
\text { (MCP-1) }\end{array}$ & In vitro & Decrease of leukocyteinfiltrate \\
\hline $\begin{array}{l}\text { Reduction of vascular } \\
\text { endothelial growth factor } \\
\text { (VEGF) }\end{array}$ & Mouse & $\begin{array}{l}\text { Decrease of monocyte infiltrate, } \\
\text { vascular permeability and } \\
\text { vasodilation }\end{array}$ \\
\hline $\begin{array}{l}\text { Reduction of transforming } \\
\text { growth factor- } \beta 1 \text { (TGF- } \beta 1 \text { ) }\end{array}$ & Human & $\begin{array}{l}\text { Reduction of the inflammatory } \\
\text { infiltrate }\end{array}$ \\
\hline $\begin{array}{l}\text { Reduction of tumor necrosis } \\
\text { factor- } \alpha \text { (TNF- } \alpha)\end{array}$ & Mouse & $\begin{array}{l}\text { Reduction of the inflammatory } \\
\text { infiltrate }\end{array}$ \\
\hline $\begin{array}{l}\text { Decrease of IL- } 6, \mathrm{IL}-8, \mathrm{IL}-1 \mathrm{~b} \text {, } \\
\mathrm{IL}-2, \mathrm{IL}-10, \mathrm{IL}-13 \text {, Interferon } \beta \\
\text { and } \mathrm{C} \text { reactive protein }\end{array}$ & $\begin{array}{l}\text { Human, } \\
\text { mouse, in vitro }\end{array}$ & $\begin{array}{l}\text { Reduction of the inflammatory } \\
\text { infiltrate, modulation of the } \\
\text { inflammatory/immune response }\end{array}$ \\
\hline $\begin{array}{l}\text { Reduction of macrophage } \\
\text { inflammatory protein-1 } \beta \text { (MIP- } \\
1 \beta)\end{array}$ & In vitro & $\begin{array}{l}\text { Reduction of the inflammatory } \\
\text { infiltrate }\end{array}$ \\
\hline $\begin{array}{l}\text { Reduction of granulocyte } \\
\text { colony-stimulating factor } \\
\text { (G-CSF) and of granulocyte } \\
\text { monocyte colony-stimulating } \\
\text { factor (GM-CSF) }\end{array}$ & In vitro & $\begin{array}{l}\text { Reduction of neutrophils } \\
\text { and activated monocytes. } \\
\text { Modulation of the inflammatory/ } \\
\text { immune response }\end{array}$ \\
\hline \multicolumn{3}{|l|}{ On oxidative stress } \\
\hline $\begin{array}{l}\text { Increase of superoxide } \\
\text { dismutase (SOD) }\end{array}$ & Mouse & $\begin{array}{l}\text { Reduction of the oxidative } \\
\text { stress ( } \downarrow \text { tissue damage) }\end{array}$ \\
\hline $\begin{array}{l}\text { Reduction of reactive oxygen } \\
\text { species (ROS) }\end{array}$ & In vitro & $\begin{array}{l}\text { Reduction of the oxidative } \\
\text { stress ( } \downarrow \text { tissue damage) }\end{array}$ \\
\hline \multicolumn{3}{|l|}{ On tissue damage } \\
\hline $\begin{array}{l}\text { Reduction of glomerular } \\
\text { heparanase- } 1\end{array}$ & In vitro & $\begin{array}{l}\text { Decreased degradation of the } \\
\text { glycocalix and the extracellular } \\
\text { matrix }\end{array}$ \\
\hline Decrease of MMP-9 & In vitro & $\begin{array}{l}\text { Decreased degradation of the } \\
\text { extracellular matrix }\end{array}$ \\
\hline \multicolumn{3}{|l|}{ On tissue repair } \\
\hline $\begin{array}{l}\text { Increase of heparan sulfate of } \\
\text { cell surface }\end{array}$ & In vitro & $\begin{array}{l}\text { Glycocalix and extracellular } \\
\text { matrix repair }\end{array}$ \\
\hline $\begin{array}{l}\text { Increase of hepatocyte growth } \\
\text { factor (HGF) }\end{array}$ & Human & $\begin{array}{l}\text { Tissue regeneration (endothelial } \\
\text { cells and other), antioxidant and } \\
\text { antiapoptotic }\end{array}$ \\
\hline $\begin{array}{l}\text { Increase of the mitogenic } \\
\text { activity of fibroblast growth } \\
\text { factor-1 and } 2 \text { (FGF-1 and } \\
\text { FGF-2) }\end{array}$ & In vitro & $\begin{array}{l}\text { Tissue re-epithelization, } \\
\text { angiogenesis }\end{array}$ \\
\hline $\begin{array}{l}\text { Increase of endothelial } \\
\text { glycocalyx thickness }\end{array}$ & Human & $\begin{array}{l}\text { Restoration of damaged } \\
\text { endothelial glycocalyx and its } \\
\text { functions }\end{array}$ \\
\hline $\begin{array}{l}\text { Restore endothelial cells } \\
\text { replication }\end{array}$ & In vitro & $\begin{array}{l}\text { Increase ability of endothelial } \\
\text { cells to heal after mechanical } \\
\text { injury }\end{array}$ \\
\hline
\end{tabular}

Table 1: Actions of sulodexide in different steps of the inflammatory process and their implications [4-6, 41-43, 46-48, 54-60].

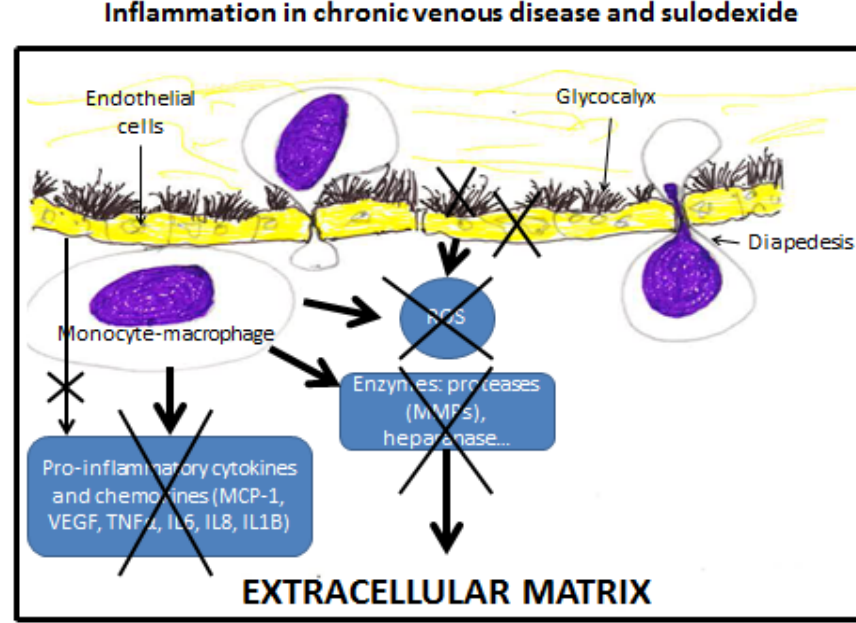

Figure 4: The steps that occur in the inflammatory process of chronic venous disease are shown; glycocalix thinning, activation of endothelial cells, diapedesis, the release of various inflammatory cytokines by endothelial cells and macrophages, the release of Reactive Oxygen Species (ROS) and the production of enzymes that may damage the extracellular matrix. The antiinflammatory actions of sulodexide marked with an " $X$ " protect the glycocalix and the endothelial cells and reduce the release of ROS, proinflammatory cytokines and proteolytic enzymes, especially MMP.

concentrations caused a dose-dependent decrease in serum MMP-9 concentration. Incubation of serum alone (therefore, without blood cells) with sulodexide had no effect, thus demonstrating that its action is not on the existent MMP concentration, but on its release by white cells. The incubation of cultured myelo-monocytic cells also demonstrated that sulodexide causes a reduction of MMP-9 release [45].

The anti-inflammatory actions of sulodexide, most of them compiled by Mattana et al. [46], are summarized in (Table 1).

Different phlebodynamic measurements suggest that treatment with sulodexide improves venous wall conditions: it reduces vein distensibility, increases venous tone, reduces maximum incremental volume upon exposure to an external obstruction with 40 or 60 $\mathrm{mmHg}$, compared to placebo, it reduces posterior tibial vein pressure compared to phlebotonics and reduces capillary filtration coefficient (Figure 3) [47-49].

The clinical translation of anti-inflammatory and phlebodynamic properties manifests as an improvement of the signs and symptoms of chronic venous disease at its different stages, including chronic venous leg ulcers (Figure 4) [25,50-53]. As can be seen in (Figure 5), sulodexide acts in the different stages of inflammation that lead to venous disease.

\section{Conclusions}

The long-term increase of blood pressure in the veins and the consequent alteration of shear stress cause endothelial glycocalyxshredding and activate endothelial cells, allowing diapedesis and inflammation of the extracellular matrix, production of Matrix Metallo Proteinases (MMP) and other proteinases, which disrupts the matrix and weakens venous walls and valves. This leads to varicose veins, greater venous hypertension, inflammatory alterations of the skin and eventually venous ulcers. Sulodexide counteracts several of the foregoing pathogeneticsteps, improves vein function and symptoms of CVD and accelerates healing of venous ulcers. 
Citation: Munari ACF, Cervera LFF (2015) Inflammation, Metalloproteinases, Chronic Venous Disease and Sulodexide. J Cardiovasc Dis Diagn 3:

\section{Changes in venous hemodynamics with sulodexide}

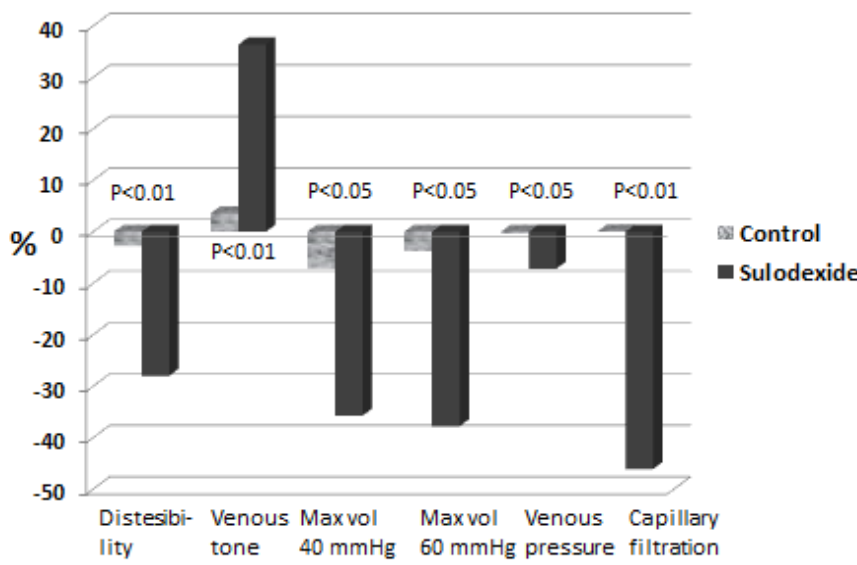

Figure 5: Percentage changes from the initial values at 90 days of treatment with sulodexide in patients with chronic venous disease. The control group received placebo, except for venous pressure, for which control was with phlebotonics. Posterior tibial vein pressure was measured in orthostatic posture. The percent values were calculated with the published data [47-49]. (Max vol = Maximum incremental volume with obstruction at 40 or $60 \mathrm{mmHg}$ ).

\section{Disclosure}

Dr. Alberto Frati is at present Medical Director of Alfa Wasserman (Mexico) producer of sulodexide. Dr. Luis Fernando Flota has been speaker for Alfa Wassermann, Bayer, Bristol, UCB, Takeda and Goretex.

\section{References}

1. Medzhitov R (2008) Origin and physiological roles of inflammation. Nature 454: 428-435.

2. Medzhitov R (2010) Inflammation 2010: new adventures of an old flame. Cell 140: 771-776.

3. García Barreno P (2008) Inflamación. Rev R AcadCiencExact Fis Nat (Esp) 102:91-15

4. Borish LC, Steinke JW (2003) Cytokines and chemokines. J Allergy Clin Immunol 111: S460-475.

5. Gabay C (2006) Interleukin-6 and chronic inflammation. Arthritis Res Ther 8 Suppl 2: S3.

6. Kishimoto T (2010) IL-6: from its discovery to clinical applications. Int Immuno 22: $347-352$

7. Lipowsky HH (2011) Protease Activity and the Role of the Endothelial Glycocalyx in Inflammation. Drug Discov Today Dis Models 8: 57-62.

8. Frati-Munari AC (2013) [Medical significance of endothelial glycocalyx]. Arch Cardiol Mex 83: 303-312.

9. Pérez-Hernández N, Ibanes-Gutiérrez C, Vargas-Alarcón G, MartínezRodríguez N, Monroy-Muñoz IE, et al. (2013) [Involvement of matrix metalloproteinases in acute coronary syndrome (ACS)]. Gac Med Mex 149: 655-667.

10. Gibson D, Cullen B, Legerstee R, Harding KG,Schultz G (2009) MMPs made easy. Wounds Int 1: 1-6

11. Jacob MP, Cazaubon M, Scemama A, Prié D, Blanchet F, et al. (2002) Plasma matrix metalloproteinase- 9 as a marker of blood stasis in varicose veins. Circulation 106: 535-538

12. Woodside KJ, Hu M, Burke A, Murakami M, Pounds LL, et al. (2003) Morphologic characteristics of varicose veins: possible role of metalloproteinases. J Vasc Surg 38: 162-169.

13. Kosugi I, Urayama H, Kasashima F, Ohtake H, Watanabe $Y(2003)$ Matrix metalloproteinase-9 and urokinase-type plasminogen activator in varicose veins. Ann Vasc Surg 17: 234-238.

14. Raffetto JD, Qiao X, Koledova VV, Khalil RA (2008) Prolonged increases in vein wall tension increase matrix metalloproteinases and decrease constriction in rat vena cava. Potential implications in varicose veins. J VascSurg 48: 447 456.

15. Weckroth M, Vaheri A, Lauharanta J, Sorsa T, Konttinen YT (1996) Matrix metalloproteinases, gelatinase and collagenase, in chronic leg ulcers. J Invest Dermatol 106: 1119-1124.

16. Vaalamo M, Mattila L, Johansson N, Kariniemi AL, Karjalainen-Lindsberg ML et al. (1977) Distinct populations of stromal cells express collagenase-3 (MMP13) and collagenase-1 (MMP-1) in chronic ulcers but not in normally healing wounds. J Invest Dermatol 109: 96-101.

17. Trengove NJ, Stacey MC, MacAuley S, Bennett N, Gibson J, et al. (1999) Analysis of the acute and chronic wound environments: the role of proteases and their inhibitors. Wound Repair Regen 7: 442-452.

18. Rayment EA, Upton Z, Shooter GK. (2008) Increased matrix metalloproteinase-9 (MMP-9) activity observed in chronic wound fluid is related to the clinical severity of the ulcer. Br J Derm 158: 951-961

19. Beidler SK, Douillet CD, Berndt DF, Keagy BA, Rich PB, et al. (2008) Multiplexed analysis of matrix metalloproteinases in leg ulcer tissue of patients with chronic venous insufficiency before and after compression therapy. Wound Repair Regen 16: 642-648.

20. Eming SA, Koch M, Krieger A, Brachvogel B, Kreft S et al. (2010) Differentia proteomic analysis distinguishes tissue repair biomarker signatures in wound exudates obtained from normal healing and chronic wounds. J ProteomeRes9: 4758-4766.

21. Liu Y, Min D, Bolton T, Nubé V, Twigg SM, et al. (2009) Increased Matrix metalloproteinase-9 predicts poor wound healing in diabetic foot ulcers. Diabetes Care 32: 117-119.

22. Reiss MJ, Han YP, Garcia E, Goldberg M, Yu H, et al. (2010) Matrix metalloproteinase-9 delays wound healing in a murine wound model. Surgery 147: 295-302.

23. Cornu-Thenard A, Boivin P, Baud JM, De Vincenzi I, Carpentier PH (1994) Importance of the familial factor in varicose disease. Clinical study of 134 families. J Dermatol Surg Oncol 20: 318-326.

24. Jawien A (2003) The influence of environmental factors in chronic venous insufficiency. Angiology 54 Suppl 1: S19-31.

25. Flota-Cervera LF, Paz-Janeiro JL, Guevara-Saldívar MI, Muñoz-Martinez TC Nuricumbo-Vázquez A, et al. (2014) Sulodexida para la enfermedad venosa crónica. Experiencia clínica en México. Rev MexAngiol 42: 28-37.

26. Agus GB, Mattana P, Carelli F (2012) Monitor 2010: Italian epidemiological survey on chronic venous diseases. ActaPhlebol 13: 9-17.

27. Frati Munari AC (2014) [Medical significance of endothelial glycocalyx. Part 2 Its role in vascular diseases and in diabetic complications]. Arch Cardiol Mex 84: $110-116$

28. Saharay M, Shields DA, Georgiannos SN, Porter JB, Scurr JH, et al. (1998) Endothelial activation in patients with chronic venous disease. Eur $\mathrm{J}$ Vasc Endovasc Surg 15: 342-349.

29. Chiu JJ, Chien S (2011) Effects of disturbed flow on vascular endothelium: pathophysiological basis and clinical perspectives. Physiol Rev 91: 327-387.

30. Tisato V, Zauli G, Voltan R, Gianesini S, di lasio MG, et al. (2012) Endothelia cells obtained from patients affected by chronic venous disease exhibit a proinflammatory phenotype. PLoS ONE 7: e39543.

31. Ono T, Bergan JJ, Schmid-Schönbein GW, Takase S (1998) Monocyte infiltration into venous valves. J Vasc Surg 27: 158-166.

32. Condezo-Hoyos L, Rubio M, Arribas SM, España-Caparrós G, RodríguezRodríguez P, et al. (2013) A plasma oxidative stress global index in early stages of chronic venous insufficiency. J Vasc Surg 57: 205-213.

33. Labropoulos N, Kang SS, Mansour MA, Giannoukas AD, Buckman J, et al (1999) Primary superficial vein reflux with competent saphenous trunk. Eur J Vasc Endovasc Surg 18: 201-206.

34. Raffetto JD, Khalil RA (2008) Mechanisms of varicose vein formation: valve dysfunction and wall dilation. Phlebology 23: 85-98. 
Citation: Munari ACF, Cervera LFF (2015) Inflammation, Metalloproteinases, Chronic Venous Disease and Sulodexide. J Cardiovasc Dis Diagn 3: 203. doi:10.4172/2329-9517.1000203

35. Smith PC (2006) The causes of skin damage and leg ulceration in chronic venous disease. Int J Low Extrem Wounds 5: 160-168.

36. Raffetto JD, Mannello F (2014) Pathophysiology of chronic venous disease. Int Angiol 33: 212-221.

37. Beidler SK, Douillet CD, Berndt DF, Keagy BA, Rich PB, et al. (2009) Inflammatory cytokine levels in chronic venous insufficiency ulcer tissue before and after compression therapy. J Vasc Surg 49: 1013-1020.

38. Hoppensteadt DA, Fareed J (2014) Pharmacological profile of sulodexide. Int Angiol 33: 229-235.

39. Mannello F, Ligi D, Raffetto JD (2014) Glycosaminoglycan sulodexide modulates inflammatory pathways in chronic venous disease. Int Angiol 33: 236-242.

40. Frati-Munari AC (2012) Glicosaminoglicanos en las enfermedades vasculares. RevMexAngiol 40: 89-99.

41. Broekhuizen LN, Lemkes BA, Mooij HL, Meuwese MC, Verberne $H$, et al. (2010) Effect of sulodexide on endothelial glycocalyx and vascular permeability in patients with type 2 diabetes mellitus. Diabetologia 53: 2646-2655.

42. Ciszewicz M, Polubinska A, Antoniewicz A, Suminska-Jasinska K, Breborowicz A (2009) Sulodexide suppresses inflammation in human endothelial cells and prevents glucose cytotoxicity. Transl Res 153: 118-123.

43. Suminska-Jasinska K, Polubinska A, Ciszewicz M, Mikstacki A, Antoniewicz A, et al. (2011) Sulodexide reduces senescence-related changes in human endothelial cells. Med Sci Monit 17: CR222-226.

44. Mannello F, Ligi D, Canale M, RaffettoJD (2014) Sulodexide down-regulates the release of cytokines, chemokines, and leukocyte colony stimulating factors from human macrophages: role of glycosaminoglycans in inflammatory pathways of chronic venous disease.CurrVascPharmacol12: 173-185.

45. MannelloF, Medda V, Ligi D, Raffetto JD (2013) Glycosaminoglycan Sulodexide inhibition of MMP-9 gelatinase secretion and activity: possible pharmacological role against collagen degradation in vascular chronic diseases.CurrVascPharmacol 11: 354-365.

46. Mattana P, MannelloF, Ferrari P, Agus GB (2012) Vascular pathologies and inflammation: the anti-inflammatory properties of sulodexide. J VascEndovascSurg 19: 1-7.

47. Cospite M, Milio G, Ferrara F, Cospite V(1992) Hemodynamic effects of sulodexide in post-thrombophlebitic syndromes. ActaTher18: 149-161.
48. Cospite M, Ferrara F, Cospite V, Palazzini E (1992) Sulodexide and the microcirculatory component in microphlebopathies. Curr Med Res Opin 13 56-60.

49. Allegra C (1993) Ruolo attuale dei glicosaminoglicani e prospettive in terapia. Minerva Angiol 18: 45-49.

50. Andreozzi GM (2012) Sulodexide in the treatment of chronic venous disease Am J Cardiovasc Drugs 12: 73-81.

51. Scondotto G, Aloisi D, Ferrari P, Martini L (1999) Treatment of venous leg ulcers with sulodexide. Angiology 50: 883-889.

52. Coccheri S, Scondotto G, Agnelli G, Aloisi D, Palazzini E, et al. (2002) Randomised, double blind, multicentre, placebo controlled study of sulodexide in the treatment of venous leg ulcers. Thromb Haemost 87: 947-952.

53. Kucharzewski M, Franec A, Hoziolek H (2003) Treatment of venous leg ulcers with sulodexide. Phlebologie 32: 115-120.

54. Deshmane SL, Kremlev S, Amini S, Sawaya BE (2009) Monocyte chemoattractant protein-1 (MCP-1): an overview. J Interferon Cytokine Res 29: 313-326.

55. Maurer M, von Stebut E (2004) Macrophage inflammatory protein-1. Int $J$ Biochem Cell Biol 36: 1882-1886.

56. Ferrara N, Gerber HP, LeCouter J (2003) The biology of VEGF and its receptors. Nat Med 9: 669-676.

57. Xu S, Höglund M, Hâkansson L, Venge $P$ (2000) Granulocyte colonystimulating factor (G-CSF) induces the production of cytokines in vivo. $\mathrm{Br}$ Haematol 108: 848-853.

58. Shi Y, Liu CH, Roberts Al, Das J, Xu G, et al. (2006) Granulocyte-macrophage colony-stimulating factor (GM-CSF) and T-cell responses: what we do and don't know. Cell Res 16: 126-133.

59. Giménez Gallego G (2002) [Fibroblast growth factors: structure-activity relations in an unusual family of multifunctional proteins]. Nefrologia 22 Suppl 5: 21-24.

60. Segura-Flores AA, Gálvez-Gastélum FJ, Alvarez-Rodríguez A, ArmendárizBorunda J (2004) [Hepatocyte growth factor (HGF) and its therapeutic applications]. Rev Gastroenterol Mex 69: 243-250. 